\title{
$244 \mathrm{LH}$
}

Draft

Published in Oxford Research Encyclopedia of Religion (March, 2017), http://religion.oxfordre.com (10.1093/acrefore/9780199340378.013.503)

\section{Martin Luther's Influence on Legal Reforms and Civil Law}

\author{
John Witte Jr.
}

\begin{abstract}
The Lutheran reformation transformed not only theology and the church but law and the state as well. Beginning in the 1520s, Luther joined up with various jurists and political leaders to craft ambitious legal reforms of church, state, and society on the strength of Luther's new theology. These legal reforms were defined and defended in hundreds of monographs, pamphlets, and sermons published by Lutheran writers from the 1520s to 1550s. They were refined and routinized in hundreds of new reformation ordinances promulgated by German cities, duchies, and territories that converted to the Lutheran cause. By the time of the Peace of Augsburg (1555) -- the imperial law that temporarily settled the constitutional order of Germany--the Lutheran Reformation had brought fundamental changes to theology and law, to church and state, marriage and family, education and charity.

Critics of the day, and a steady stream of theologians and historians ever since, have seen this legal phase of the Reformation as a corruption of Luther's original message of Christian freedom from the strictures of human laws and traditions. But Luther ultimately realized that he needed the law to stabilize and enforce the new Protestant teachings. Radical theological reforms had made possible fundamental legal reforms. Fundamental legal reforms, in turn, would make palpable radical theological reforms. In the course of the 1530s onwards, the Lutheran Reformation became in its essence both a theological and a legal reform movement. It struck new balances between law and Gospel, rule and equity, order and faith, structure and spirit.
\end{abstract}

Keywords: Church, State, Law, Politics, Marriage, Education, Charity, Two Kingdoms, Natural Law, Positive Law, Equity, Criminal Law, Punishment, Uses of the Law, Legal Reformations, Church Ordinances

\section{Introduction}


The Lutheran Reformation brought fundamental reforms not only to theology and the church, but also to law and the state. The radical theological reforms introduced by Luther and his colleagues triggered major legal reforms in sixteenth-century Germany and Scandinavia. These new Protestant laws, in turn, helped to establish and enforce the new norms and practices of theology and polity, doctrine and liturgy, church and state, marriage and education, charity and morality, and these remained in place in Lutheran lands until the twentieth century.

\section{Law and Politics in the Two Kingdoms}

The starting point for these reforms of law and religion was Luther's complex theory of the two kingdoms. God has ordained two kingdoms or realms in which humanity is destined to live, Luther argued, the earthly kingdom and the heavenly kingdom. The earthly kingdom is the realm of creation, of natural and civil life, where a person operates primarily by reason and law. The heavenly kingdom is the realm of redemption, of spiritual and eternal life, where a person operates primarily by faith and love. These two kingdoms embrace parallel heavenly and earthly, spiritual and temporal forms of righteousness and justice, government and order, truth and knowledge. But these two kingdoms ultimately remain distinct. The earthly kingdom is distorted by sin and governed by the law. The heavenly kingdom is renewed by grace and guided by the gospel. A Christian is a citizen of both kingdoms at once and invariably comes under the distinctive government of each. As a heavenly citizen, the Christian remains free in his or her conscience, called to live fully by the light of the word of God alone. But as an earthly citizen, the Christian is bound by law, and is called to obey the natural orders and offices that God has ordained for the governance of this earthly kingdom. ${ }^{1}$

Luther's two-kingdoms theory turned the traditional hierarchical theory of spiritual and temporal authority on its side. For centuries, the church had taught that the pope is the vicar of Christ, in whom Christ has vested the "plentitude of his power." This power was symbolized in the "two swords" discussed in the Bible (Luke 22:38) - the spiritual and the temporal swords. Christ had handed these two swords to the highest being in the human world-the pope, the vicar of Christ. The pope and his clerical delegates wielded the spiritual sword, in part by establishing canon laws for the governance of all of Christendom. The pope, however, was too holy to wield the temporal sword. He thus delegated this sword to those authorities below the spiritual realm-emperors, kings, dukes, and other political officials. These civil magistrates were to promulgate and enforce state laws in a manner consistent with canon law and church teachings. State law was thus by its nature inferior to canon law. Political authority was subordinate to clerical authority. 
Luther rejected this hierarchical view of government. For Luther, the earthly kingdom featured three natural "estates" (Stände) or forms of authority: the family, the church, and the state. These three estates stood equal before God and each other. Each was called directly by God to discharge complementary tasks in the earthly kingdom. The family was called to rear and nurture children, to teach and to discipline them, to cultivate and exemplify love and charity within the home and the broader community. The church was called to preach the word, to administer the sacraments, to catechize the young, and to discipline its members. The state was called to protect peace, punish crime, promote the common good, and to support the church, family, and other institutions derived from them.

Not only were these three estates equal, rather than hierarchical, Luther continued; only the state had formal legal authority - the authority of the sword to pass and enforce positive laws for the governance of the earthly kingdom. The church was not a law-making authority. It had no sword, no jurisdiction, no canon law, and no courts. To be sure, pastors and theologians were expected to preach and prophesy in promotion of justice, order, and the common good. Each local church needed internal rules of order to govern its members and officers, and external legal structures to protect its polity and property. But it was up to the local magistrate to pass and enforce all such church laws in consultation and cooperation with the local clergy and theologians. ${ }^{2}$

Luther was more concerned with the function than with the form of the state. He had hoped that the emperor would endorse the Reformation, and accordingly included in his early writings some lofty panegyrics about Christian emperors ancient and modern. When the emperor failed him, Luther turned at various times to the nobles, princes, and peasants, and in turn wrote favorably about each of them. ${ }^{3}$ Such writings must be read in their immediate political context, however, and not used to paint Luther as a theorist of political absolutism, elitist oligarchy, or constitutional democracy. Luther had no firm or consistent theory of the forms of political office. He did not sort out systematically the relative virtues and vices of monarchy, aristocracy, or democracy. He said little about thorny constitutional law questions of the nature, purpose, and institutionalization of executive, legislative, and judicial power.

Luther focused instead on the general status and function of the political office-both before God and within the community. On the one hand, Luther regarded the magistrate as God's vice-regent in the earthly kingdom, called to elaborate and enforce God's Word and will, to reflect God's justice and judgment on earthly citizens. The magistracy was, in this sense, a "divine office" and a "Godly calling," within the earthly kingdom. "Law and earthly government are a great gift of God to mankind," Luther wrote with ample flourish. "Earthly authority is an image, shadow, and figure of the dominion of Christ." But magistrates also exercise God's judgment and wrath against human sin. "Princes and magistrates 
are the bows and arrows of God," equipped to hunt down God's enemies near and far, using military strength and criminal power. The hand of the Christian magistrate, judge, or soldier "that wields the sword and slays is not man's hand, but God's." 4

On the other hand, Luther believed, the magistrate was the "father of the community" (Landesvater). He was called to care for his political subjects as if they were his children, and his political subjects were to "honor" him as if he were their parent. Like a loving father, the magistrate was to keep the peace and to protect his subjects from threats or violations to their persons, properties, and reputations. He was to deter his subjects from abusing themselves through drunkenness, sumptuousness, prostitution, gambling, and other vices. He was to nurture and sustain his subjects through the community chest, the public almshouse, the state-run hospice. He was to educate them through the public school, the public library, the public lectern. He was to see to their spiritual needs by supporting the ministry of the locally established church, and encouraging their attendance and participation through the laws of Sabbath observance, tithing, and holy days. He was to see to their material needs by reforming inheritance and property laws to ensure more even distribution of the parents' property among all children. He was to set an example of virtue, piety, love, and charity in his own home and private life for his faithful subjects to emulate and to respect. The Christian magistrate was to complement and support the God-given responsibilities of parents and family members for their children and dependents, without intruding on the paternal office. And he was to support the preaching and sacramental life of the local church without trespassing on the ecclesiastical office. $^{5}$

These twin metaphors of the Christian magistrate-as the lofty vice-regent of God and as the loving father of the community-described the basics of Luther's political theory and constitutional law. For Luther, political authority was divine in origin but earthly in operation. It expressed God's harsh judgment against sin but also his tender mercy for sinners. It communicated the law of God but also the lore of the local community. It depended upon the church for prophetic direction, but it took over from the church all legal jurisdiction. Either metaphor standing alone could be a recipe for abusive tyranny or officious paternalism; but both metaphors together provided Luther and his followers with the core ingredients of a robust Christian republicanism and budding Christian welfare state.

\section{Natural and Positive Law in the Earthly Kingdom}

What kept the life of the earthly kingdom intact and in order, Luther believed, was the law of God, and its elaboration and enforcement by the political authorities. Luther defined the law of God as the set of norms ordained by God in the creation, written by God on the hearts of all persons, and rewritten by God 
on the pages of the Bible. He called this variously the "law of nature," "natural law," "divine law," "Godly law," "the law of the heart," "the teachings of conscience," "the inner law," among others-terms and concepts that he did not clearly differentiate either from each other or from traditional formulations. ${ }^{6} \mathrm{His}$ main point was that God's natural law set at creation continued to operate after the fall into sin, and it provided the foundation for all positive law and public morality in the earthly kingdom.

The natural law defined the basic duties that a person owed to God, neighbor, and self. For Luther, the clearest expression of these obligations was the Ten Commandments. The First Table of the Decalogue set out basic duties and rights to honor the Creator God, to respect God's name, to observe the Sabbath, to avoid idolatry and blasphemy. The Second Table set out basic obligations to respect one's neighbor-to honor authorities, and not to kill, commit adultery, steal, bear false witness, or covet. Luther believed this to be a universal statement of natural law. "The Decalogue is not the law of Moses ... but the Decalogue of the whole world, inscribed and engraved in the minds of all men from the foundation of the world." "[W]hoever knows the Ten Commandments perfectly must know all the Scriptures, so that, in all affairs and cases, he can advise, help, comfort, judge, and decide both spiritual and temporal matters, and is qualified to sit in judgment upon all doctrines, estates, spirits, laws, and whatever else is in the world."7

Knowledge of this natural law comes not only through revealed scripture, Luther argued, but also through natural reason and conscience. Luther echoed St. Paul's notion that all persons have a "law written in their hearts," and thus every rational person "feels" and "knows" the law of God. "For they carry with them in the recesses of the heart a living book which would tell them more than enough about what they ought to do, judge, accept, and reject." ${ }^{8}$ But sinful persons do not, of their own accord, readily heed the natural law. Thus, God has called upon other persons and authorities in the earthly kingdom to elaborate its basic requirements. All Christians, as priests to their peers, must communicate the natural law of God by word and by deed. Parents must teach it to their children and dependents. Preachers must preach it their congregants and catechumens. And magistrates must elaborate and enforce it through their positive laws and public policies.

The magistrate's elaboration and enforcement of the natural law through positive laws was particularly important, Luther believed, since only the magistrate held formal legal authority in the earthly kingdom. "Natural law is a practical first principle in the realm of public morality," Luther wrote; "it forbids evil and commands good. Positive law is a decision that takes local conditions into account," and "credibly" elaborates the general principles of the natural law into specific precepts to fit these local conditions. "The basis of natural law is God, who has created this light, but the basis of positive law is the earthly authority" 
who uses his faith, reason, and tradition to develop just laws for the community. The magistrate must pray to God earnestly for wisdom and instruction. He must maintain "an untrammeled reason" in judging the needs of his people and the advice of his counselors. He must summon the wisdom of the legal traditionparticularly that of Roman law, which Luther called a form of "heathen wisdom."

The magistrate must apply the law equitably, Luther insisted. "The strictest law [can do] the greatest wrong." Thus, "equity is necessary"; indeed, any magistrate "who does not know how to dissemble does not know how to rule." To apply a rule equitably, Luther insisted "is not rashly to relax laws and discipline." It is, rather, to balance firmness and fairness and to recognize circumstances that might mitigate against literal application of a rule or that might raise new issues that a rule does not and perhaps should not reach. In such instances, "equity will weigh for or against" strict application of the rule, and a wise ruler will know the juster course. "But the weighing must be of such kind that the law is not undermined."10 Lutheran jurist, Johann Oldendorp, later weaved Luther's insights into a novel and comprehensive Christian theory of law, justice, and equity. ${ }^{11}$

\section{The Uses of the Law and the Purposes of Criminal Punishment}

Luther's famous doctrine of justification by faith alone made clear that neither natural law nor positive law provided a pathway to salvation, or a stairway from the earthly kingdom to the heavenly kingdom. Nonetheless, Luther insisted, the law still has important "uses" in this earthly life that require its constant maintenance and cultivation. One such use of the law is to restrain people from sinful conduct by threat of punishment. Luther called this the "civil use" of the law. God wants even the worst of sinners to observe the basic law of God and the state -- to honor their parents, to avoid killing and stealing, to respect marriages and households, to testify truthfully, and the like -- so that "some measure of earthly order, concourse and concord may be preserved." Sinners, not naturally inclined to observe the law, may be compelled to do so by fear of punishment -- divine punishment as well as human punishment. "Stern hard civil rule is necessary in the world," Luther wrote, "lest the world be destroyed, peace vanish, and commerce and common interest be destroyed." Indeed, if the magistrate "does not punish murder and bloodshed, although he could, he is himself guilty of the same murders and wrongs that those villains commit." 12

A second use of the law is to reveal to all people their sin and induce them to seek God's grace. Luther called this the "theological use" of the law. The law in this sense serves as a mirror in which a sinner can reflect upon his depravity and see behind him the beckoning hand of a gracious God ready to forgive him and welcome him into the heavenly kingdom. Luther sometimes put this in 
harsher terms: "The chief and proper use of the Law is to reveal to man his sin, blindness, misery, wickedness, ignorance, hate, contempt of God, death, hell, judgment, and the well-deserved wrath of God.... When the law is being used correctly, it does nothing but reveal sin, work wrath, accuse, terrify, and reduce minds to the point of despair." From out of the depths of this despair, the sinner will cry to God for forgiveness and salvation. ${ }^{13}$

Luther touched on a third "educational use" of the law as well. Law, in this sense, serves to teach the faithful, those who have already been justified by faith, the good works that please God. Luther made clear that even the faithful remain sinful and in need of God's constant instruction through the law. He recognized that sermons, commentaries, and catechism lessons on the many Old Testament passages on law are directed, in no small part, to teaching the faithful the meaning of God's law. He wrote cryptically early in his career of the "three-fold use of the law" and said that the "law touches the heart and moves it, so that a man not only ceases to persecute, but ... desires to be better." But Luther never systematically expounded a third use of the law. ${ }^{14}$

Luther's close colleague and worker Philip Melanchthon did expound all three uses of the law, and he used this doctrine to systematize and extend Luther's scattered reflections on the nature and purpose of criminal law and punishment. ${ }^{15}$ Like Luther, Melanchthon believed that the state had to develop a new and separate body of criminal law to replace both the medieval canon law of crimes and the Catholic Church's detailed rules governing the sacrament of penance. The state had to prohibit major crimes like treason, murder, rape, theft, rape, burglary, and adultery as it always had done. But the state now had to prohibit many other major and minor offenses as well that were traditionally governed by church laws and courts. These included religious offenses heresy, sorcery, witchcraft, alchemy, blasphemy, sacrilege, Sabbath-breaking, tithe-breaking, false oaths, and more. They included various family and sexual offenses - wife and child neglect and abuse, malicious desertion, seduction and fornication, prostitution, pornography, voyeurism, exhibitionism, and more. And they included a growing number of offenses against "public morality and policy" (Polizei) - drunkness and debauchery, sumptuousness and waste, perjury and fraud, trade, labor, and economic crimes, proper conduct in taverns, shops, and lodgings, embezzlement, usury, and banking irregularities, false weights and measures, passport and travel violations, and much more. ${ }^{16}$ All this, said Melanchthon, helped the state law achieve the "civil use" of deterring bad and harmful conduct, the "theological use" of inducing persons to ask God and the church for help in living an upright life, and the "educational use" of learning how to love God, neighbor, and self in public and private. ${ }^{17}$

Moreover, the state's criminal law had to balance firmness and equity, severity and temperance as Luther had said. First, magistrates had to stop using torture to extract confessions from the defendant. Not only were these coerced 
confessions often unreliable as evidence in criminal cases. But such confessions did the defendant's soul no good. Medieval Catholic authorities regarded confession as an essential first step in receiving the sacrament of penance, without which the sinner faced eternal punishment in hell. A one-time act of bodily torture was thought to be a small price to pay for eternal life of the soul. Luther and his followers rejected the sacrament of penance and the underlying rationale for torture. Every sinner had to confess directly to God, without the mediation, let alone coercion, of church or state authorities. Second, magistrates had to draw more refined distinctions between degrees of criminality and to prescribe a broader range of punishments short of execution. As Luther put it: "criminal courts should not fill the country with widows and orphans." 18 The refined differentiation of mortal and venial sins and their punishment that historically attached to the church's sacrament of penance, were now to be attached to the state's criminal laws and punishments. Third, magistrates had to work not only to retribute the crime but also to reform the criminal. This was the "educational use of the law" in action. Especially Melanchthon and later Lutheran and Calvinist reformers emphasized the importance of rehabilitating convicted defendants, consigning them to public work programs, workhouses, and penitentiaries (Zuchthausen) and furnishing them with chaplains, pastors, and teachers to bring them back to a level of sociability and morality, if not piety and spiritual integrity. All these criminal justice reforms were only partly achieved in the sixteenth century, and they had other sources of inspiration besides Protestant theology - not least legal humanism and new Catholic criminal jurisprudence..$^{19}$ But the Reformation was an important source and catalyst for these criminal law reforms in Protestant Germany and Scandinavia. ${ }^{20}$

\section{The New Lutheran Church Ordinances}

Background. The Lutheran Reformation helped reform not only the law of church and state, and crime and punishment, but several other areas of law as well. These legal reforms built not only Luther's "theological" reforms, but also on a "legal reformation" movement that had begun a century before Luther. Beginning with Cologne in 1437, several German cities passed what they called "legal reformations" (Rechtsreformationen). These were major new pieces of legislation, some in excess of 100 dense folio pages. They included the famous legal reformations of Nürnberg, Hamburg, Tübingen, Worms, Frankfurt am Main, and Freiburg im Breisgau, passed between 1479 and 1520, that were echoed and excerpted by several smaller towns. They also included the new reformation laws of the territories of Baden, Franken, Bavaria, and Erbach, and a whole series of statutes that sought to reform criminal law, criminal procedure, and criminal courts in Würzburg, Nürnberg, Tyrol, Bamberg, Laibach, among others. ${ }^{21}$

These pre-Reformation "legal reformations" aimed, in part, to routinize and reform the civil laws and procedures of these local polities. At minimum, they 
reduced a good deal of local customary law to writing, and shifted more legal responsibility from the church to the state. More fully, these legal reformations aimed to update and integrate these local laws to some extent -- sometimes plucking provisions from the many learned medieval texts and commentaries of Roman law and canon law as well as from the new reformation laws already on the books in neighboring German polities. Later laws, such as the Reformation of Worms (1498) and the Statute of Freiburg im Breisgau (1520), were veritable codes of the new local private laws of contracts, property, inheritance, and more that largely replaced earlier canon law and civil law systems. The same is true of some of the territorial laws of the 1500s and 1510s on criminal law and procedure (Halsgerichtsordnungen), like the famous Bambergensis of 1507 that put in place comprehensive new rules of evidence, proof, and punishment in criminal cases.

These fifteenth-century legal reformations were a critical precursor to the legal reforms born of the Protestant Reformation. The Protestant reformers simply adopted and accepted many of these pre-Reformation legal reforms. The Protestant reformers sometimes offered new rationales and accents for these new laws, as we just saw with criminal law. But they largely accepted the new laws that had already been enacted. What they added were new laws and ordinances designed to distill, communicate, and enforce their most important new teachings. In the early years of the Protestant Reformation, these were sometimes called "legal reformations" as well, echoing fifteenth-century terminology. They eventually came to be called Protestant or Evangelical "church ordinances" (Kirchenordnungen), even though they included a number of topics beyond church life. Each town, city, and territory that converted to the Protestant cause usually had a new such "church ordinance" in place within a decade of its conversion. ${ }^{22}$ Hundreds of these Lutheran reformation ordinances have survived from the sixteenth century - a score of them drafted by Luther and Melanchthon, and many others drafted by leading Lutheran theologians like Johannes Bugenhagen, Johannes Brenz, and Andreas Osiander. ${ }^{23}$

While these Lutheran "church ordinances" were very wide-ranging in subject matter, sophistication, and detail, they typically had lengthy provisions on: (1) religious doctrine, liturgy, and worship, and local forms of church administration and supervision; (2) spiritual morality; (3) poor relief and other forms of social welfare; (4) sex, marriage, and family life; and (5) education and public schools.

Religious Doctrine and Ecclesiastical Polity. A great number of the new legal provisions reflected and routinized the many new changes in doctrine, liturgy, and polity introduced by Luther and his followers. These included rules on the resystematization of dogma; the truncation of the sacraments; the reforms of liturgy, devotional life, and the religious calendar; the vernacularization of the Bible, liturgy, and sermon; the expansion of catechesis and religious instruction 
in lower schools and universities; the revamping of corporate worship, congregational music, religious symbolism, church art and architecture; the radical reforms of ecclesiastical discipline and local church administration; the new practices of tithing, baptism, confirmation, weddings, burial; diaconal care, sanctuary, and much more. All these aspects of spiritual life had been governed in detail by the Catholic canon law and the church's sacramental rules. They were now subject to the laws of the state, set out in these Lutheran church ordinances. Particularly after the Peace of Augsburg (1555) confirmed the constitutional principle that each civil ruler was to establish the religion of his own local polity (cuius regio eius religio), these rules and regulations became increasingly detailed and ornate.

Spiritual Morality. Another set of ordinances sought to govern the spiritual morality of church members. This was subject to intense canon law and sacramental rule-making in the Middle Ages, and it was the most dramatic area of legal change born of the early Reformation. In his early writings, Luther had railed against the canon law and sacramental rules as self-serving "human traditions" that intruded on the Christian conscience and abridged "the freedom of the Christian." "Neither pope nor bishop nor any other man has the right to impose a single syllable of law upon a Christian man without his consent," Luther wrote famously in 1520. "In the entire canon law of the pope there are not even two lines which could instruct a devout Christian," he wrote. "[T]here are so many mistakes and dangerous laws that nothing would be better than to make a bonfire of it." "It would be a good thing if canon law were completed blotted out, from the first letter to the last, especially the [papal] decretals. More than enough is written in the Bible about how we should behave in all circumstances." "Unless they will abolish their laws and ordinances and restore to Christ's churches their liberty and have it taught among them, they are guilty of all the souls that perish under this miserable captivity, and the papacy is truly the kingdom of Babylon and of the very Antichrist." ${ }^{24}$ After such radical pronouncements, it was no surprise that Luther burned the canon law and confessional books in his famous 1520 bonfire in Wittenberg.

But Luther soon realized that they he had drawn too sharp a contrast between spiritual freedom and disciplined orthodoxy within the church. Young Lutheran churches, clerics, and congregants were treating their new liberty from the canon law as license for all manner of doctrinal and liturgical experimentation and moral laxness. Widespread confusion reigned over preaching, prayers, sacraments, funerals, holidays, and pastoral duties. Church attendance, tithe payments, and charitable offerings declined abruptly among many who took literally Luther's new teachings of free grace. Many radical egalitarian and antinomian experiments were engineered out of Luther's doctrines of the priesthood of believers and justification by faith. 
It was in response to this that Luther, Melanchthon, and other reformers in the later 1520 s began to insist on developing internal rules of morality for church leaders and members to match the internal rules of order for church life. Luther turned to the princes and city councilors as "emergency bishops" to include new laws of spiritual morality as part of the new church ordinances. A good number of these laws ran parallel to the new criminal laws that we just saw. These included laws governing church attendance and tithe payments, unnecessary labor and uncouth leisure on Sundays and holy days. Other laws prohibited blasphemy, sacrilege, witchcraft, sorcery, magic, alchemy, false oaths, and similar offenses. Sumptuary laws proscribed immodest apparel, wasteful living, and extravagant feasts, weddings, and funerals. Entertainment laws placed strict limits on public drunkenness, boisterous celebration, gambling, and other games that involved fate, luck, and magic. All these moral offenses were now regarded as sins to be punished by church authorities using spiritual sanctions, such as public confessions, fines, charitable works, bans from the Eucharist, or excommunication.

The sixteenth-century church ordinances were not always clear or consistent, however, in drawing lines between sins punished by church authorities and crimes punished by the state authorities. A Lutheran church member guilty of wrongdoing could be subject to both spiritual sanctions and criminal punishment by the state, and the authorities evidently had little sympathy with pleas about double jeopardy. In some cases involving religious officials those double sanctions made sense: a church sexton who maliciously abused or deserted his spouse, a pastor who embezzled church tithes or fornicated with a congregant, or a catechism teacher who secretly ran a brothel or gambling house betrayed both church and state communities and deserved the sanctions of both institutions. But in other cases, say of petty theft or skipping worship, the double sanctions seemed unduly harsh. Given the volume of new state criminal and policy ordinances, born of the Reformation, it took some local polities some time to sort out these lines between sin and crime, spiritual sanction and criminal punishment. ${ }^{25}$

Poor Relief and Social Welfare. The new laws reforming poor relief and social welfare were a considerably more eclectic combination of Lutheran and humanist learning. The medieval church taught that both poverty and charity were spiritually edifying. Voluntary poverty was a form of Christian sacrifice and self-denial that conferred spiritual benefits upon its practitioners and provided spiritual opportunities for others to accord them their charity. Itinerant monks and mendicants in search of alms were the most worthy exemplars of this ideal, but many other deserving poor were at hand as well. Voluntary charity, in turn, conferred spiritual benefits upon its practitioner, particularly when pursued as a work of penance and purgation in the context of the sacraments of penance or extreme unction. To be charitable to others was to serve Christ, who had said, 
"Inasmuch as you have done it unto one of the least of these my brethren, you have done it unto me" (Matt. 25:40).

These teachings helped to render the medieval Church, at least in theory, the primary object and subject of charity and social welfare. To give to the Church was the best way to give to Christ, since the Church was the body of Christ on earth. The Church thus received alms through the collections of its mendicant monks, the charitable offerings from its many pilgrims, the penitential offerings assigned to cancel sins, the final bequests designed to expedite purgation in the life hereafter, and much more. The Church also distributed alms through the diaconal work of the parishes, the hospitality of the monasteries, and the welfare services of the many Church-run almshouses, hospices, schools, chantries, and ecclesiastical guilds. A rich latticework of canonical and confessional rules calibrated these obligations and opportunities of individual and ecclesiastical charity, and governed the many charitable corporations, trusts, and foundations under the Church's general auspices.

Luther and other reformers rejected these traditional teachings on the spiritual idealization of poverty and the spiritual efficaciousness of charity. All persons were called to work the work of God in the world, they argued. They were not to be idle or to impoverish themselves voluntarily. Voluntary poverty was a form of social parasitism to be punished, not a symbol of spiritual sacrifice to be rewarded. Only the worthy local poor deserved charity, and only if they could not be helped by their immediate family members, the family being the first school of charity. Charity, in turn, was not a form of spiritual self-enhancement. It was a vocation of the priesthood of believers. Charity brought no immediate spiritual reward to the giver. Instead, it brought spiritual opportunity to the receiver. The Lutheran doctrine of justification by faith alone undercut the spiritual efficacy of charity for the giver. Salvation came through faith in Christ, not through charity to one's neighbor. But the Lutheran doctrine of the priesthood of all believers enhanced the spiritual efficacy of charity for the receiver. Those who were already saved by faith became members of the priesthood of all believers. They were called to love and serve their neighbors charitably in imitation of Christ. Those who received the charity of their neighbors would see in this personal sacrificial act the good works brought by faith, and so be moved to have faith themselves. ${ }^{26}$

Such Lutheran teachings accorded well with some of the anti-begging sentiments and laws of late medieval German cities and territories. The Lutheran reformers adopted and expanded these anti-begging laws with alacrity in the early 1520 s and thereafter, often adorning these laws with ample discussion of their belief that it was every Christian's duty to work in a vocation and to avoid idle parasitism. ${ }^{27}$ Such Evangelical teachings also accorded somewhat with traditional understandings of what Brian Pullan has aptly called "redemptive charity"--that charity is a means of bringing the receiver into salvation. ${ }^{28}$ 
The Protestant reformers, however, also went beyond these late medieval teachings and legal reforms. Led by Luther's early denunciation of celibacy and monasticism ${ }^{29}$ they outlawed monasticism altogether and confiscated monastic properties, sometimes forcibly. They translated their belief in the spiritual efficacy of the direct personal relationship between the giver and the receiver into a new emphasis on local charity for the local poor, without dense administrative bureaucracies. Particularly the complex tangle of ecclesiastical guilds, endowments, foundations, and other charitable institutions of the church were, for the early reformers, not only economically inefficient but spiritually ineffacious. The "redemptive charity" that the reformers had in mind came more in the direct personal encounter between the faithful giver and the grateful receiver, not so much in the conventional notion that the receiver should experience and receive charity within a church institution.

The Lutheran reformers also rejected the traditional belief that the church was to be the primary object and subject of charity. For the local church to receive and administer charity beyond its immediate congregation, and to run monasteries, almshouses, charities, hospices, foundations, orphanages, and more detracted from its essential mission. The local parish church should continue to receive the tithes of its members, as biblical laws taught. It should continue to tend to the immediate needs of its local members, as the apostolic church had done. But most other gifts to the church and the clergy were, in the reformers' view, misdirected. Most other forms of ecclesiastical charity, particularly those surrounding pilgrimages, penance, and purgation, were, for the reformers, types of "spiritual bribery," predicated on the fabricated sacraments of penance and extreme unction and on the false teachings of purgatory and works righteousness. ${ }^{30}$

In place of traditional ecclesiastical charities, the reformers instituted a series of local civil institutions of welfare, usually administered directly by local townsfolk. Built on late medieval prototypes, these local welfare systems were centered on the community chest, administered by the local magistrate, and directed to the local, worthy poor and needy. The community chest, whose early rules Luther set out in an important Wittenberg Ordinance of 1522 and Lesnig Ordinance of 1523, was, at first comprised of the church's monastic properties and endowments that had been confiscated. These community chests were eventually supplemented by local taxation and private donation. In larger cities and territories, several such community chests were established, and the poor closely monitored in the use of their services. At minimum, this system provided food, clothing, and shelter for the poor, and emergency relief in times of war, disaster, or pestilence. In larger and wealthier communities, the community chest eventually supported the development of a more comprehensive local welfare system featuring public orphanages, workhouses, boarding schools, vocational centers, hospices, and more, administered or supervised by the local magistrate. These more generous forms of social welfare were poignant 
expressions of Luther's ideal of the Christian magistrate as the "father of the community," called to care for all the needs of his political children.

Marriage and Family Life. Luther and other reformers worked to reform not only church and state but also marriage and the family. Prior to the sixteenth century, marriage was regarded as a sacrament of the church. It was formed by the mutual consent of a fit man and a fit woman in good religious standing. It symbolized the enduring union of Christ and his church, and conferred sanctifying grace upon the couple and their children. The parties could form this union in private, but once properly formed it was an indissoluble bond broken only by the death of one of the parties. As a sacrament, marriage was subject to the jurisdiction of the medieval church. A complex network of canon laws governed sex, marriage, and family life in detail, from abortion to euthanasia. The church did not regard the family as its most exalted estate, however. Although a sacrament and a sound way of Christian living, marriage (and with it, family life) was not considered to be spiritually edifying. Marriage was a remedy for sin, not a recipe for righteousness. Marriage was considered subordinate to celibacy. Clerics and monastics were required to forgo marriage as a condition for ecclesiastical service. Those who could not were not worthy of the church's holy orders and offices.

Luther took on this traditional theological and legal teachings in five major tracts on marriage. ${ }^{31} \mathrm{He}$ and his fellow reformers treated marriage, not as a sacrament of the heavenly kingdom, but as a social estate of the earthly kingdom. Marriage, they taught, was a natural institution that served the goods of mutual love and support of husband and wife, mutual procreation and nurture of children, and mutual protection of both spouses from sexual sin. All adult persons, preachers and others alike, should pursue the calling of marriage, for all were in need of the comforts of marital love and of the protection from sexual sin. Moreover, the marital household served as a model of authority, charity, and pedagogy in the earthly kingdom and as a vital instrument for the reform of church, state, and civil society. Parents served as "bishops" to their children. Siblings served as priests to each other. The household altogether was a source of evangelical and charitable impulses in society.

Though divinely created and spiritually edifying, however, marriage remained a social estate of the earthly kingdom. All parties could partake of this institution, regardless of their faith or lack of it. Though guided by biblical norms and clerical counseling, marriage and family life were subject to the rule of the state, not the church. Civil magistrates were to set the laws for marriage formation, maintenance, and dissolution; child custody, care, and control; family property, inheritance, and commerce and more.

Lutheran magistrates rapidly translated this new Protestant gospel of marriage into civil law. They passed new civil marriage laws that shifted marital 
jurisdiction from the church to the state. They strongly encouraged the marriage of clergy, discouraged celibacy, and prohibited monasticism. They denied the sacramentality of marriage and the religious tests and spiritual impediments traditionally imposed on prospective marital couples. They simplified the doctrine of consent to betrothal and marriage, and required the participation of parents, peers, priests, and political officials in the process of marriage formation and dissolution. They sharply curtailed the number of impediments to marriage. And they introduced absolute divorce on proof of adultery, desertion, and other faults, with a subsequent right to remarriage at least for the innocent party. Almost every one of these legal reforms Luther had advocated and defended in his early writings.

Education and Schooling. The Lutheran reformers soon extended their reforms to schools, which Luther called little churches, little states, and little families at once. Prior to the sixteenth century, schools were dominated by the church. Cathedrals, monasteries, chantries, ecclesiastical guilds, and large parishes offered the principal forms of lower education in Germany, governed by general and local canon law rules of the church. Gifted graduates were sent on to church-licensed universities for advanced training in the core faculties of law, theology, and medicine. The vast majority of students, however, were trained for clerical and other forms of service in the church.

Luther also took on this medieval tradition, too, in two major tracts and several smaller pamphlets on establishing public schools for children. ${ }^{32}$ The Lutheran Reformation transformed this church-based school system into a new system of public schools that allowed each youngster to prepare for his or her own distinctive Christian calling. In the reformers' view, the magistrate, as "father of the community," was primarily responsible for the schooling of his political "children." Education was to be mandatory for boys and girls alike. It was to be fiscally and physically accessible to all. It was to be marked by both formal classroom instruction and civic education through community libraries, lectures, and other media. The curriculum was to combine biblical and evangelical values with humanistic and vocational training. Students were to be stratified into different classes, according to age and ability, and slowly selected for any number of vocations. The public school was to be, in Philip Melanchthon's famous phrase, the "civic seminary" of the commonwealth designed to combine deep faith and deep learning. As the Reformation unfolded in Germany, the local Protestant magistrate replaced the local Catholic bishop as the chief protector and cultivator of the public school and university. The state's civil law replaced the church's canon law as the chief law governing education. The Bible replaced the scholastic text as the chief handbook of the curriculum. German replaced Latin as the universal tongue of the educated classes in Germany. The general callings of all Christians replaced the special calling of the clergy as the essence of education. ${ }^{33}$ 


\section{Luther's Legal Legacy}

Nearly half a millennium after it first broke out in the little town of Wittenberg, the Lutheran Reformation still exerts influence on Western law, politics, and culture. Today, in most Western legal systems, marriage is still viewed by many as both a civil and a spiritual institution, as Luther taught, whose formation and dissolution require special legal procedures. Parents must still consent to the marriages of their minor children. Peers must still attest to the veracity of the marital oath. Pastors or political officials must still confirm the marital union, if not consecrate it. Divorce and annulment still require a special public proceeding before a tribunal, with proof of support for dependent spouses and children.

Today, in most Western legal systems, basic education remains a fundamental right of the citizen to procure and a fundamental duty of the state to provide. Literacy and learning are still considered a prerequisite for individual flourishing and communal participation. Society still places a heavy burden on those who shirk education voluntarily. The state is still the essential monitor of civil education, which task it discharges directly through its own public or common schools, or indirectly through its accreditation and supervision of private schools, including religious schools.

Today, in most Western legal systems, care for the poor and needy remains an essential office of the state and an essential concern of the citizen. The rise of the modern Western welfare state over the past century is in no small measure a new institutional expression of the Lutheran ideal of the magistrate as the father of the community called to care for all his political children. The concurrent rise of the modern philanthropic citizen is, in no small measure, a modern institutional expression of Luther's ideal of the priesthood of all believers, each called to give loving service to neighbors. Sixteenth-century Lutherans and twenty-first-century Westerners seem to share the assumption that the state has a role to play not only in fighting wars, punishing crime, and keeping peace but also in providing education and welfare, fostering charity and morality, facilitating worship and piety. They also seem to share the assumption that law has not only a basic use of coercing citizens to accept a morality of duty but also a higher use of inducing citizens to pursue a morality of aspiration.

Much of our modern Western struggle with law, however, is also part of the legal legacy of the Lutheran Reformation. For example, the Lutheran reformers removed the church as the spiritual ruler of Germany in expression of their founding ideals of religious liberty. But they ultimately anointed the state as the new spiritual ruler of Germany in expression of their new doctrines of Christian republicanism. Ever since, Germany and other Protestant nations have 
been locked in a bitter legal struggle to come to grips with the legacy of state establishments of religion while also allowing religious freedom for all.

The Lutheran reformers removed the pope who, in their view, impugned the Christian conscience, fleeced the sheep of Christendom, and reduced the German people to quivering obedience for fear of their eternal life. But the reformers ultimately anointed the secular prince as the new vice-regent of God on earth, the summus episcopus, with too few constitutional safeguards against his tyrannical excesses and too few intellectual resources to support civil disobedience, let alone political revolt.

The Lutheran reformers removed clerics as mediators between God and the laity, in expression of St. Peter's teaching of the priesthood of all believers. But they ultimately interposed husbands between God and their wives, in expression of St. Paul's teaching of male headship within the home. The Lutheran reformers outlawed monasteries and cloisters. But these reforms also ended the vocations of many single women, placing a new premium on the vocation of marriage. Ever since, Protestant women have been locked in a bitter legal struggle to gain fundamental equality both within the marital household and without-a struggle that continues in more conservative Protestant communities today.

Luther's legal legacy, therefore, should be neither unduly romanticized nor unduly condemned. Those who champion Luther as the father of liberty, equality, and fraternity might do well to remember his ample penchant for elitism, statism, and chauvinism. Those who see the reformers only as belligerent allies of repression and abuse should recognize that they were also benevolent agents of education and welfare. Prone as he was to dialectic reasoning, and aware as he was of the inherent virtues and vices of human achievements, Luther would likely have reached a comparable assessment.

\section{Review of the Literature}

Luther's legal and political thought has been intensely studied for more than a century, particularly after his Werke were published at the turn of the twentieth century. For convenient excerpts of his writings from WA and LW, see Hermann W. Beyer, Luther und das Recht, repr. ed. (Salzwasser-Verlag Gmbh, 2013) and J.M. Porter, ed., Luther--Selected Political Writings (Philadelphia: Fortress Press, 1974). Among many recent studies, see Johannes Heckel, Lex Charitatis: A Juristic Disquisition on Law in the Theology of Martin Luther, trans. Gottfried G. Krodel (Grand Rapids, MI: William B. Eerdmans, 2010); W.D.J. Cargill Thompson, The Political thought of Martin Luther, ed. Philip Broadhead (Totawa, NJ: Barnes and Nobles, 1984); and John Witte, Jr., Law and 
Protestantism: The Legal Teachings of the Lutheran Reformation (Cambridge: Cambridge University Press, 2002).

Luther's influence on law and politics was amply studied by such nineteenth-century giants as Roderich von Stintzing and Ernest Landesberg, Geschichte der deutschen Rechtswissenschaft, 6 vols. repr. ed. (Aalen: Scientia Verlag, 1978). Among newer studies see Harold J. Berman, Law and Revolution II: The Impact of the Protestant Reformations on the Western Legal Tradition (Cambridge, MA: Harvard University Press, 2003); Virpi Mäkinen, ed., Lutheran Reformation and the Law (Leiden: Brill, 2006); and Mathias Schmoeckel, Das Recht der Reformation (Tübingen: Mohr Siebeck, 2014).

Luther's influence over discrete areas of law has also been intensely studied. On Lutheran church ordinances, see the critical edition of Emil Sehling, et al., eds., Evangelischen Kirchenordnungen des XVI. Jahrhunderts, 24 vols. (Leipzig: O.R. Reisland, 1902- ) and analysis in Karla Sichelschmidt, Recht aus christlicher Liebe oder obrigkeitlicher Gesetzesbefehl? Juristische Untersuchungen zu den evangelischen Kirchenordnungen des 16. Jahrhunderts (Tübingen: J.C.B. Mohr, 1995); Wilhelm Maurer, Die Kirche und ihr Recht: Gesammelte Aufsätze zum evangelischen Kirchenrecht (Tübingen: Mohr, 1976); Martin Heckel, Gesammelte Schriften: Staat, Kirche, Recht, Geschichte, ed. Klaus Schlaich, 6 vols. (Tübingen: J.C.B. Mohr (Paul Siebeck), 1989-2013).

For marriage and family law reforms, see Hartwig Dieterich, Das Protestantische Eherecht in Deutschland bis zur Mitte des 17. Jahrhunderts (München: Claudius Verlag, 1970); Ralf Frassek, Eherecht und Ehegerichtsbarkeit in der Reformationszeit: Der Aufbau neuer Rechtsstrukturen im sächsischen Raum unter besonderer Berücksichtigung der Wirkungsgeschichte des Wittenberger Konsistoriums (Tübingen: Mohr Siebeck, 2005); Steven Ozment, When Fathers Ruled: Family Life in Reformation Europe (Cambridge, MA: Harvard University Press, 1983); and John Witte, Jr., From Sacrament to Contract: Marriage, Religion, and Law in the Western Tradition, 2d ed. (Louisville, KY: Westminster John Knox Press, 2012).

For charity and social welfare legal reforms, see Larry Frohman, Poor Relief and Welfare in Germany from the Reformation to World War I (Cambridge: Cambridge University Press, 2008); Robert Jütte, Poverty and Deviance in Early Modern Europe (Cambridge: Cambridge Univerisity Press, 2006); Carter Lindberg, Beyond Charity: Reformation Initiatives for the Poor (Minneapolis:

Fortress Press, 1993); and Thomas Max Safley, The Reformation of Charity: The Secular and the Religious in Early Modern Poor Relief (Boston: Brill Academic Publishers, 2003).

On the reforms of education law, see Sebatian Kreiker, Armut, Schule, Obrigkeit: Armenversorgung und Schulwesen in den evangelischen 
Kirchenordnungen des 16. Jahrhunderts (Bielefeld Verl. für Regionalgeschichte 1997); Gerald Strauss, Luther's House of Learning: Indoctrination of the Young in the German Reformation (Baltimore, MD: Johns Hopkins University Press, 1978); and F.V.N. Painter, Luther on Education, repr. ed. (Eugene, OR: Wipf and Stock, 2001).

\section{Further Reading List}

Berman, Harold J., Law and Revolution II: The Impact of the Protestant Reformations on the Western Legal Tradition (Cambridge, MA: Harvard University Press, 2003) Gmbh, 2013)

Beyer, Hermann W., Luther und das Recht, repr. ed. (Salzwasser-Verlag

Dieterich, Hartwig, Das Protestantische Eherecht in Deutschland bis zur Mitte des 17. Jahrhunderts (München: Claudius Verlag, 1970)

Frassek, Ralf, Eherecht und Ehegerichtsbarkeit in der Reformationszeit: Der Aufbau neuer Rechtsstrukturen im sächsischen Raum unter besonderer Berücksichtigung der Wirkungsgeschichte des Wittenberger Konsistoriums (Tübingen: Mohr Siebeck, 2005)

Heckel, Johannes, Lex Charitatis: A Juristic Disquisition on Law in the Theology of Martin Luther, trans. Gottfried G. Krodel (Grand Rapids, MI: William B. Eerdmans, 2010)

Jütte, Robert, Poverty and Deviance in Early Modern Europe (Cambridge: Cambridge Univerisity Press, 2006)

Lindberg, Carter, Beyond Charity: Reformation Initiatives for the Poor (Minneapolis: Fortress Press, 1993) 2006)

Mäkinen, Virpi, ed., Lutheran Reformation and the Law (Leiden: Brill,

Painter, F.V.N., Luther on Education, repr. ed. (Eugene, OR: Wipf and Stock, 2001).

Porter, J.M., ed., Luther--Selected Political Writings (Philadelphia: Fortress Press, 1974). 
Schmoeckel, Mathias, Das Recht der Reformation (Tübingen: Mohr Siebeck, 2014).

Sehling, Emil, et al., eds., Evangelischen Kirchenordnungen des XVI. Jahrhunderts, 24 vols. (Leipzig: O.R. Reisland, 1902- )

Sichelschmidt, Karla, Recht aus christlicher Liebe oder obrigkeitlicher Gesetzesbefehl? Juristische Untersuchungen zu den evangelischen Kirchenordnungen des 16. Jahrhunderts (Tübingen: J.C.B. Mohr, 1995)

Witte, John, Jr., Law and Protestantism: The Legal Teachings of the Lutheran Reformation (Cambridge: Cambridge University Press, 2002).

\footnotetext{
${ }^{1}$ See detailed sources in John Witte, Jr., Law and Protestantism: The Legal Teachings of the Lutheran Reformation (Cambridge: Cambridge University Press, 2002), 87-118 [hereater LP]. ${ }^{2}$ LW 45:105ff.; LW 36:106ff.

${ }^{3}$ See texts in K. Trüdinger, Luthers Briefe und Gutachten an weltliche Obrigkeit zur Durchfuhrung der Reformation (Münster: Aschendorff, 1975); J.M. Porter, ed., Luther-Selected Political Writings (Philadelphia: Fortress Press, 1974).

${ }^{4}$ LW 2:139ff.; LW 13:44ff.; LW 17:171; LW 44:92ff.; LW 45:85ff.; LW 46:95ff., 237ff.; WA 6:267; WA 19:626; WA 30/2:554.

${ }^{5}$ LW 13:44ff.; LW 36:106-17; LW 45:85-113; LW 46:225ff.

${ }^{6}$ See texts in Hermann W. Beyer, Luther und das Recht, repr. ed. (Salzwasser-Verlag Gmbh, 2013) and analysis in Johannes Heckel, Lex Charitatis: A Juristic Disquisition on Law in the Theology of Martin Luther, trans. Gottfried G. Krodel (Grand Rapids, MI: Wm. B. Eerdmans, 2010).

${ }^{7}$ LW 44:15-114; WA 39/1:478, 540; WA 18:72; WA 30:192.

${ }^{8}$ WA 17/2:102.

9 WA TR 3, no. 3911; WA 12:243; WA 14:591, 714; WA 16:537; WA 30/2:557; WA 40:305; WA 51:211, 241-42; LW 45:120-26.

10 WA TR 3, no. 4178; LW 54:325; WA TR 1, no. 315; LW 54:43-44; WA 14:667ff.; LW 46:100.

11 See LP 154-68.

12 WA 10:454; WA 11:251; WA 15:302; WA 18:360, 388-91.

13 WA, 40:481-86.

${ }^{14}$ WA 6:196ff.; WA 10/1:449, 457; LW 47:99ff.; WA 38:310. See discussion in Edward

Engelbrecht, Friends of the Law: Luther's Use of the Law for Christian Life (St. Louis, MO:

Concordia Publishing House, 2011).

${ }^{15}$ Corpus Reformatorum - Melanchthons Werke, 28 vols., G. Bretschneider et al, ed.

(Braunschweig: C.A. Schwetschke, 1834), 1:706-709; 11:666; 21:405-406, 716-19 [hereafter CR];

Phililp Melanchthon, Melanchthon on Christian Doctrine: Loci Communes (1555), ed. and trans.

Clyde Manschrek (New York/Oxford: Oxford University Press, 1965), 54-57, $122-8$.

${ }^{16}$ See Mathias Schmoeckel, Das Recht der Reformation: Die epistemologische Revolution der

Wissenschaft und die Spaltung der Rechtsordnung in der frühen Neuzeit (Tübingen: Mohr

Siebeck, 2014), 207-37; Heikki Pihlajamäki, "Executor Divinarum et Suarum Legum: Criminal Law
} 
and the Lutheran Reformation," in Lutheran Reformation and the Law, ed. Virpi Mäkinen (Leiden: Brill, 2006), 171-204.

${ }^{17}$ CR 21:405-406, 716-19;CR 22:224.

18 WA 11:234; CR 3:244-58; CR 11:775-83; see also Mathias Schmoeckel, "Nemesis: A Historical Glimpse into the Christian Reasons for Punishment," Tijdschrift voor Rechtsgeschiedenis 81 (2013): 159, 177-82.

${ }_{19}$ Schmoeckel, Das Recht der Reformation, 237-45; John H. Langbein, Prosecuting Crime in the Renaissance: England, Germany, France (Cambridge, MA: Harvard University Press, 1974).

${ }^{20}$ Pihlajamäki, "Executor Divinarum," 192-202; John Witte, Jr., God's Joust, God's Justice: Law and Religion in the Western Tradition (Grand Rapids, MI: Wm. B. Eerdmans, 2006), 263-94.

${ }^{21}$ See collection in Wolfgang Kunkel, et al., eds., Quellen zur Neueren Privatrechtgeschichte Deutschlands, 2 vols. (Weimar: H. Böhlau, 1936).

22 See details sources in LP 177-98.

${ }^{23}$ See collection in Emil Sehling, et al., eds., Evangelischen Kirchenordnungen des XVI. Jahrhunderts, 24 vols. (Leipzig: O.R. Reisland, 1902- ) and analysis and sources in Karla Sichelschmidt, Recht aus christlicher Liebe oder obrigkeitlicher Gesetzesbefehl? Juristische Untersuchungen zu den evangelischen Kirchenordnungen des 16. Jahrhunderts (Tübingen: J.C.B. Mohr, 1995).

${ }^{24}$ LW 36:70-75; LW 44:179-82, 202-203; LW 48:274-276.

${ }^{25}$ Hans Grünberger, "Institutionalisierung des protestantischen Sittendiskurses," Zeitschrift für historische Forschung 24 (1997): 215-252; Dietmar Willoweit, "Die Expansion des Strafrechts in Kirchenordnungen des 16. Jahrhunderts," in Herrshaftliches Strafen seit dem Hochmittelalter: Formen und Entwicklungsstufen (Köln/Weimar/Wien: Böhlau, 2002), 331-54.

${ }^{26}$ LW 31:29, 204; LW 35:46; LW 44:193; LW 49:27; see analysis in Robert Jütte, Poverty and Deviance in Early Modern Europe (Cambridge: Cambridge Univerisity Press, 2006); Carter Lindberg, Beyond Charity: Reformation Initiatives for the Poor (Minneapolis: Fortress Press, 1993); Abby Phyllis Knobler, Luther and the Legal Concept of the Poor in Sixteenth-Century German Church Ordinances (Ann Arbor, MI: UMI Press, 1992); Harold J. Grimm, "Luther's Contribution to Sixteenth-Century Organization of Poor Relief," Archif für Reformationsgeschichte 61 (1970): 222.

${ }^{27}$ Lindberg, Beyond Charity, 9ff.

${ }^{28}$ Brian Pullan, "Support and Redeem: Charity and Poor Relief in Italian Cities from the Fourteenth to the Seventeenth Centuries," Continuity and Change 3 (1988): 177, 188.

${ }^{29}$ Sources in LP 61-65, 223-24.

30 LW 35:45-73; LW 45:273-310.

${ }^{31}$ Sources in LP, 199-256 and John Witte, Jr. From Sacrament to Contract: Marriage, Religion, and Law in the Western Tradition, 2nd ed. (Louisville, KY: Westminster John Knox Press, 2012), 113-58.

32 Sources in F.V.N. Painter, Luther on Education, repr. ed. (Eugene, OR: Wipf and Stock, 2001).

${ }^{33}$ Sources in LP, 257-92. 